\title{
Rwanda Legal Framework on Insolvency: Problems and Proposals for Reform
}

\author{
Ngaundje Doris Leno* \\ Centre for Advanced Corporate and Insolvency Law, University of Pretoria, Pretoria, South Africa
}

\begin{abstract}
The purpose of this article is to explore some key insolvency issues, which will be highly selective for this article, and to identify the weaknesses and inconsistencies in the existing framework on insolvency. Rwanda does not have an efficient and effective framework on insolvency, and the article argues that there is a need for an improved insolvency law regime. In view of the weaknesses and inconsistencies, it is vital to consider international best practices such as the United Nations Commission on International Trade Law (UNGITRAL) Legislative Guide on Insolvency and the UNCITRAL Model Law on Cross-border Insolvency as the basis needed to deal with different aspects or elements of the Rwanda insolvency law. The value of this article lies in the insights it offers into the current framework on insolvency and the opportunity given to address the inconsistencies, weaknesses and uncertainties that invariably arise from the law. Copyright C 2015 INSOL International and John Wiley \& Sons, Ltd
\end{abstract}

\section{Introduction}

The Republic of Rwanda ('country of a thousand hills') is a small country in terms of surface area, ${ }^{1}$ with an expanding population of over 11.46 inhabitants. $^{2}$ It is situated in East Africa and borders the Democratic Republic of Congo in the West, Uganda in the North, Tanzania in the East and Burundi in the South. Rwanda operates a mixed legal system of civil law that is heavily based on the

*E-mail: dorisleno2008@gmail.com

This article draws on work carried out at a time when the author was the insolvency advisor at the Office of the Registrar General (ORG), Rwanda Development Board (RDB), Kigali, Rwanda. RDB is gratefully acknowledged. 1. The surface area $(\mathrm{sq} \mathrm{km})$ in Rwanda was last reported at 26340 in 2010, according to a World Bank Report published in 2012, available at: <http://www. tradingeconomics.com/rwanda/surface-area-sq-km-wbdata.html > (last accessed 14 January 2014).
2. This is following the fourth Rwanda Population and Housing Census in August 2012. The census was effected in accordance with the Presidential Order No. 02/01 of 07/02/2011, available at: < https://www. google.rw/\#q=Rwanda + population $+>$ (last accessed 10 January 2014). As of July 2014, the population was estimated at 12.34 million; see Rwanda Demographic Profile 2014 available at: http://www. indexmundi.com/rwanda/demographic_profile.html (last accessed 23 February 2015). 
Belgian civil law system and the English common law. This is following the country's integration of the English common law system. ${ }^{3}$ For Nick Johnson, Rector of the Rwanda Institute of Legal Practice and Development, 'such a decision is a pragmatic move forward." ${ }^{4}$ The mixed legal system is capaciously embraced by Rwandans, and for the former High Court president, Johnston Busingye,

We [Rwanda] prefer hybrid law; we have the commercial law and other laws of procedures (almost 400) and other amended laws that have very big convergence to common law to answer Rwanda problems. ${ }^{5}$

It is instructive to note that Rwanda's move or shift from the continental civil law to a hybrid system was not only necessitated by the country's membership of the East African Community (EAC) or the Commonwealth ${ }^{6}$ but also by the country's desire to increase local investment and improve the standard of living of the people. ${ }^{7}$ For Appleton,

it is driven in part by a desire to distance the country's legal system from the 1994 genocide that saw up to a million people murdered - but also to accelerate the integration of the country into the EAC trade bloc. ${ }^{8}$

Rwanda is in effect a mixed legal system blending common law and civil law in the commercial sphere. ${ }^{9}$ The challenge faced by Rwandans is working in the different official languages (French, English and Kinyarwanda), ${ }^{10}$ translating words and concepts into another language: Kinyarwanda, a language widely spoken and used by the people and judges in the courtroom. Consequently, it will take time for all to get acquainted with the reform process and to generate the skills needed for the application and implementation of the applicable commercial laws. ${ }^{11}$

As far as insolvency is concerned, it is largely regulated by the law relating to commercial recovery and settling of issues arising from insolvency (RIL). ${ }^{12}$ The goal of the RIL generally is to enable a quick commercial recovery and settlement of issues arising from insolvency. ${ }^{13}$ In 2013, the author commenced an investigation of the RIL in its entirety, which culminated in the 'modified insolvency law' ${ }^{14}$ The modified insolvency law is designed to improve on the mechanisms

3. E Kosar 'Rwanda's tradition from Civil to Common law', available at: < http://www.oba.org/ getattachment/Sections/International-Law/Articles/ Articles-2013/July-2013/Rwanda \%E2\%80\%99s-

Transition-from-Civil-to-Common-Law/

Rwanda \%E2\%80\%99 s-Transition-from-Civil-toCommon-Law.pdf > (last accessed 21 December 2013) (hereinafter referred to as Kosar E).

4. Cited in S Appleton 'Africa: Rule of Law in Africa, adaptive behaviour' available at: http:// www.ibanet. org/Article/Detail.aspx?ArticleUid=17621b67-2482455c-9900-2b69ce220599 (last accessed 19 January 2014).

5. See 'EAC wants Rwanda, Burundi to adopt common law' available at: <systemhttp://www.newtimes. co.rw/news/views/article_print.php?i $=13914 \& \mathrm{a}=$ 16230\&icon=Print $>$ (last accessed 12 January 2014).
6. Rwanda joined the East African Community on 1 July 2007 and the Commonwealth in November 2009. 7. E Kosar, before note 3 .

8. Id.

9. Id.

10. Id.

11. Id.

12. Law No. $12 / 2009$ of 26/05/2009 relating to commercial recovery and settling of issues arising from in solvency (RIL) as modified and complemented by Law $\mathrm{N}^{\circ} 35 / 2013$ of 29/05/2013 relating to commercial recovery and settling of issues arising from insolvency ('Modified insolvency law').

13. RIL, art 3.

14. Modified insolvency law, before note 12 . 
employed for commercial recovery and settlement of issues arising from insolvency in particular reorganization and liquidation mechanisms, and to modify and complement the previous distribution list. The modified insolvency law brought about certain amendments regarding the grounds for commencement of insolvency proceedings, ${ }^{15}$ the time limit for the submission of a reorganization plan, implementation of an automatic stay of creditors' enforcement actions and the distribution of proceeds realized from the sale of insolvent estates. ${ }^{16}$

Taking into account these recent developments in Rwanda, this article highlights three important issues regarding the current insolvency law. The first is that Rwanda does not have an efficient and effective insolvency framework to help creditors recover their claims because it lacks well-defined provisions. Secondly, the reform of the RIL will significantly improve the practice of insolvency leading to a speedy and efficient resolution of insolvency disputes in Rwanda and, thirdly, the Legislative Guide ${ }^{17}$ and the Model Law ${ }^{18}$ can serve as the basis for reform of the RIL. The purpose of this article is to explore some key insolvency issues, which will be highly selective, and to identify the weaknesses in the existing framework on insolvency.

\section{The Current Framework on Insolvency}

The RIL is the legal basis for commercial recovery and the settlement of insolvency disputes in Rwanda. The RIL is not a comprehensive piece of legislation, in that it does not provide for both personal and corporate insolvencies and it is uncertain whether unitary legislation will be adopted in the near future to provide for all types of debtors. The RIL is confined to insolvency proceedings open against a debtor, that is, to corporations and individual persons exercising trade as their profession (traders). ${ }^{19}$ Financial institutions such as insurance companies and banks are governed by the provisions of this law subject to special rules regulating these institutions. ${ }^{20}$ Also, the RIL does not provide for debtors operating beyond the borders of Rwanda (cross-border insolvency) but applies to a foreign debtor operating in the country. ${ }^{21}$ In the words of article 322 of the Law Relating to Companies (Companies Law), ${ }^{22}$ a foreign debtor must be registered by the registrar

15. Id, art 1.

16. Id, art 7. See International Bank of Reconstruction and Development (World Bank) and International Finance Corporation Doing Business 2014 understanding regulations for small \& medium-size enterprises (2013, World Bank Publications) at 168.

17. UNCITRAL Legislative Guide on Insolvency 25 June 2004 (Legislative Guide), available at: http:// wwwuncitral.org/pdf/english/texts/insolven/05-80722 Ebook.pdf (last accessed 2 May 2011) (hereinafter referred to as Legislative Guide).

18. 30 May 1997 (Model Law). Available at: < http:// www.uncitral.org/pdf/english/texts/insolven/insolvency-e.pdf $>$ (last accessed 23 April 2013).
19. RIL, art 1. Art 1 does not provide a definition for the term 'debtor' but provides 'the law governs all commercial recovery and settling of issues arising from insolvency whether related to a trader or a company'. 20. Id, art 101. Law No. 08/6/1999 as modified by Law No. 08/2002 of 05/02/2002 Governing Banks and other financial Institutions.

21. Id, art 98 .

22. Law No. $07 / 2009$ OF $27 / 04 / 2009$ relating to Companies (Companies Law) as amended by Law No. 14/2010 of 07/05/2010 ('Modified Company Law'). 
general (RG) in charge of registration of companies and security interests before it can be subjected to insolvency proceedings in Rwanda.

Suffice to say that the RIL remains the principal source of Rwanda's insolvency law, the RIL is read with the Instructions of the (RG) on insolvency ${ }^{23}$ that details the powers of the RG regarding the supervision and regulation of the insolvency industry. However, in the event of insolvency, reference may be made to the Companies' Law: the Law on Mortgages that focuses on the effective enforcement of the rights of individual creditors, ${ }^{24}$ Law on Security Interests in Movable Property $^{25}$ and Law regulating Labour in Rwanda (Labour Law). ${ }^{26}$

It is submitted that every well-functioning market economy needs an efficient insolvency system, the importance of which cannot be overemphasized. An efficient and effective insolvency system builds confidence among credit providers, resulting in increased credit and depleted borrowing costs. ${ }^{27}$ It facilitates the resuscitation of viable businesses, thereby maximizing the going concern value and preserving jobs. ${ }^{28}$ It also benefits entrepreneurs and lowers the rate of liquidation of distressed firms. ${ }^{29}$ Many governments have undertaken profound changes to strengthen their insolvency system. ${ }^{30}$ Rwanda is not left out in the reform process. Despite Rwanda's efforts to reform its legal framework on insolvency, there are still many inconsistencies and weaknesses in the existing framework that in the author's view contributes to the country's poor performance in resolving insolvency (resolution of insolvency disputes). Said Francois Kanimba, minister of Trade and Commerce, 'if I take indicator related to insolvency proceedings, we are among the countries really who are not performing well worldwide'. ${ }^{31}$ Kanimba attributes the problem 'to the slow pace at which [the RIL] is applied'. ${ }^{32}$

\section{A. What is insolvency and when is a debtor said to be insolvent?}

In accordance with article 1 of the modified insolvency law, the term 'insolvency' is defined as the inability of a debtor to pay his debts when they are due (cash flow insolvency) and when a debtor is over indebted (balance sheet insolvency). It follows therefore that an insolvent is a debtor who is unable to pay his or her debts as they fall due or who is over indebted. Accordingly, persons with capacity may

23. No. $01 / 2012 /$ ORG of $04 / 04 / 2012$ relating to Commercial Recovery and Settling of Issues Arising from Insolvency (RG Instructions on insolvency).

24. Law No. 10/2009 of 14/05/2009 on Mortgages Modified and Completed by Law No. 13/2010 of 07/05/2010 (Mortgage Law).

25. Law No. 11/2009 of 14/05/2009 on Security Interests in Movable Property (Security Law on Movable Property).

26. Law No. 13/2009 of 27/05/2009 regulating Labour in Rwanda (Labour Law).

27. International Monetary Fund (IMF) 'Orderly \& effective insolvency procedures: key issues', <http:// www.imf.org/external/pubs/ft/orderly/> (last accessed 23 January 2014). See Organization for Economic Co-operation and Development (OECD)
Insolvency systems in Asia: An efficiency Perspective (2001) 8 .

28. Id.

29. Id.

30. Uganda established explicit rules on the enforcement of the duties of liquidators during liquidation proceedings while Mozambique adopted a new legal framework on insolvency in 2013; see < http:www. doingbusiness.org/data.exploretopics/resolving-of-insolvency/reforms $>$ (last accessed 15 February 2015). 31. See 'Rwanda plans insolvent law awareness campaign', available at: http://en.igihe.com/business/ rwanda-plans-insolvent--law-awareness- campaign (last accessed 25 January 2014).

32. Cited in 'Registrar challenges creditors to make use of the insolvency law' New Times 1. 
rely on the inability and indebtedness of a debtor to trigger insolvency proceedings. Emphatically, there is the lack of mechanisms for the administration of debtors with insufficient assets to defray the costs of proceedings. Consequently, insolvency proceedings cannot be opened against debtors with insufficient assets to defray the costs of proceedings. When this happens, the court shall not appoint an insolvency administrator and shall determine the distribution of the debtor's assets. ${ }^{33}$

On the other hand, the Companies Law makes the insolvency procedure to be predicated on article 353 of the Companies Law. Article 353 of the Companies Law describes circumstances when a company will be deemed insolvent. By the provisions of article 353

A company shall be considered to be unable to pay its debts where: $1^{\circ}$ a creditor to whom the company is indebted in a sum exceeding twenty thousand Rwanda francs (20,000 Rwf), has served at the registered office a demand under his/her hand or under the hand of his/her Lawfully authorized agent requiring the company to pay the sum due, and the company has for three weeks thereafter neglected to pay the sum or to secure it to the reasonable satisfaction of the creditor; $2^{\circ}$ execution or other process issued on a judgment or order of any Court in favour of a creditor of the company is returned unsatisfied; $3^{\circ}$ it is proved to the satisfaction of the Court that the company is unable to pay its debts, having regard to its existing, contingent and prospective liabilities.

In practice, failure to pay taxes to Rwanda Revenue Authority serves as an indicator of the debtors' inability to pay his or her debts while the debtor's balance sheet serves as indication of the debtor's indebtedness. ${ }^{34}$ These defining factors help to 'minimize dissipation of assets and avoid a race by creditors to grab assets available to the body of creditors. ${ }^{35}$ The statutory provisions on insolvency are dispersed in disparate pieces of legislations that are not in keeping with the country's goal of establishing itself as the main commercial hub within the EAC region. The incorporation of article 353 of the Companies Law into the insolvency law will enhance clarity and access to the law by members of the corporate sector.

\section{B. Commencement of insolvency proceedings}

Insolvency refers to the financial condition of a debtor, while bankruptcy is the legal procedure by which an entity is adjudged bankrupt and the process is premised on the inability and indebtedness of a debtor. Practically, once a debtor defaults in his tax payment, the debtor, board of directors, creditors and the RG may file for insolvency stating the applicant's interest and reasons why insolvency proceedings should be commenced against the debtor. This is against a fee of Rwf 4500 (\$6.5). ${ }^{36}$ Although it is not clear on what basis the RG is supposed to file for insolvency, it can be postulated that it is on the basis of information furnished by the shareholders or employees of the insolvent debtor. There is no specialized

33. Modified insolvency law, art 1.

34. See Rwanda Focus 'Supplement: new measures to deal with, and avoid insolvency', available at: <http:// focus.rw/wp/2013/05/supplement-new-measures-to- deal-with-and-avoid-insolvency/> (last accessed 15 January 2014).

35. Legislative Guide page 45 para 23.

36. RIL, art 16. 
insolvency court but commercial courts for the settlement of insolvency and other disputes such as criminal, administrative and labour disputes. In terms of article 4 of the RIL, the commercial court within which the debtor is domiciled has exclusive jurisdiction over an insolvency dispute. Article 4 indicates the jurisdiction for commencement of proceedings involving a natural person but is silent on that relating to a corporate body. ${ }^{37}$ Therefore, in instances such as this, the role of the court is to refer to article 2 (3) of the Companies Law in terms of which a company's address is the place of its registered office or principal place of business.

Upon receipt of the application for commencement of insolvency proceedings, the competent commercial court may impose a general prohibition against the transfer of the debtor's assets or appoints a temporary administrator ${ }^{38}$ to manage the debtor's property and in particular to 'examining for the court whether the activities of the debtor shall be sold off or if there is any hope of their continuity'. ${ }^{39}$ This latter phrase that is contained in article 19 (4) of the RIL is not clear, and it is left for the courts to interpret the precise meaning. Nevertheless, it is submitted that it may be interpreted as meaning that once a temporary administrator is appointed, he is expected to investigate the debtor's affairs and to determine whether the debtor is viable. The granting of an insolvency order (reorganization and liquidation) hinges on the temporary administrator's report. In COSTRA-Ltd ${ }^{40}$ case, for example, the court ordered for dissolution [liquidation] of the company's assets without the temporary administrator's report, and the question always is how the courts will determine the chances of a business recovery without proper investigation of the debtor's affairs? This is a major challenge in the insolvency process that may lead to an abuse of insolvency proceedings such as the granting of liquidation proceedings instead of reorganization proceedings. Along the same lines, there was departure from the prescribed rule or regulation by the court in the $l$ Amicale $L t d^{41}$ case. It was a case of misunderstanding between shareholders over the management position and not insolvency, but the judge designated an administrator for the administration of the company's estate.

A liquidation order is granted where there is no prospect for rescue. It is comforting to note that only an insolvent company and a foreign company that ceases to operate or lug out its activities in Rwanda could be wound-up by the court or board of directors. Liquidation by board of directors commences on the date of the meeting convened to consider the appointment of a liquidator or administrator. ${ }^{42}$ Apparently, when a company is insolvent, the company director is required to convene a meeting of the board of directors within 5 days to consider the appointment of a liquidator or administrator, failing which the director will be liable for any loss incurred. ${ }^{43}$

37. Id, art 4 provides 'The Commercial Court with jurisdiction in which the debtor is domiciled shall have exclusive jurisdiction'.

38. Id, art 18.

39. Id, art 19 (4).

40. Judgment Rcom 0624/12/TC/Nyge of 28 December 2012.
41. Judgment Rcom 0441/06/TGI/Nyge of 28 December 2003.

42. Companies Law, art 218.

43. Id. 
On the other hand, a reorganization order would be granted against a viable debtor, that is, a financially troubled debtor that is capable of survival by maintaining its economic activities, preserving jobs and settling outstanding debts. Business rescue is not a dominant theme in the country, but there are efforts to encourage rescue of viable companies. ${ }^{44}$ This notwithstanding, when a company is insolvent and there is prospect of rescue, various options can be considered instead of liquidation. ${ }^{45}$ A financially distressed company may proceed with restructuring with the aim of protecting the competitiveness of the enterprise through proposal of the transfer of either a whole or part of a debtor's assets ${ }^{46}$, merger of the debtor with one or more persons ${ }^{47}$, sale of a whole or part of the debtor's assets ${ }^{48}$ and distribution of a whole or part of the debtor's assets. ${ }^{49}$ The debtor may also reach a compromise with his creditors that would assist in overcoming his financial difficulties. ${ }^{50}$ Compromise is freely available, but the costs incurred in organizing and conducting a meeting of creditors for the purpose of voting on [the] proposed compromise are met by the debtor. ${ }^{51}$ Compromise has a 'cram-down' effect on both the debtor and his or her creditors. ${ }^{52}$ In other words, once a compromise is approved, it remains binding on the debtor and his creditors. The benefit of this procedure is that it gives debtors longer timeframe for discharge of debts.

It should be made clear that the provision on discharge does not apply in insolvency. Debtors are required to pay the full amount of the debt, but in practice, creditors have not been able to recover the full amount of their claims for a number of reasons ranging from low market price of the mortgaged asset, absconding of debtors, ${ }^{53}$ the failure on the part of the competent court to seize and safely keep the property of the debtor ${ }^{54}$ and insufficiency of assets. In the CASSAVA Co. Ltd v Development Bank of Kigali Ltd $(B R D)^{55}$ case, the creditor (BRD) was not fully paid because of insufficient proceeds. BRD had a concurrent claim for its outstanding balance that of course could not be met because the debtor had no other registered property. Although the lack of a remedy to this problem does not discourage lenders, it affects the recovery rates in the country.

The silence of the RIL on the time limit for commencement of insolvency proceedings provides yet another challenge. The RIL does not set the time at

44. See the Tender Notice No. 05/S/NOCB/RBLC$\mathrm{ORG} / \mathrm{RDB} / \mathrm{ICF} / 13$ published on 05/12/2013 requesting for the services of a corporate restructuring expert to rescue viable companies in the country available at: <http://www.rdb.rw/fileadmin/user upload/Documents/tender/2.pdf $>$ (last accessed $1 \overline{2}$ December 2013).

45. RIL, art 7 (9) provides that 'the insolvency administrator may design programs and identify procedures for reviving business activities of the debtor'.

46. Id, art 80 (2).

47. Id, art $80(3)$,

48. Id, art $80(4)$

49. Id, art $80(5)$

50. Companies Law, art 311.

51. Id.
52. Id, art 315.

53. DN International Ltd Judgment Rcom 0189/12/TC/ Nyge rendered on 15 February 2013. In this case, the debtor absconded for fear of being arrested by the government. The case is still ongoing, and the major creditor Kenya Commercial Bank (KCB) has been authorized by the RG to dispose of the company's assets via auction for settlement of its claims and that of others (KCB has a right of retention over his securities). See also T Jean de la Croix 'DN International saga: Suppliers turn on KCB' The New Times 14 October 2013 at 1 (hereinafter referred to as $\mathrm{T}$ Jean de la Croix).

54. RIL, art 42.

55. Judgment Rcom 0189/01/TC/Nyge rendered on 8 December 2012. 
which applicants are supposed to file for insolvency. This gives debtors the opportunity to pursue other options such as disappearing from the country, name change of the debtor and closing down of businesses. This is evident in a number of cases, one of which is the ongoing $D \mathcal{N}$ International $L t d^{\overline{6}}$ case. DN International is a real estate company whose head, a Kenyan-born Nathan Lloyd, left the country in 2011 in an attempt to avoid payment of his debts. ${ }^{57}$ In Experco Des Grands Lacs, ${ }^{58}$ although a government ministry, it changed its name from Ministry of Lands, Environment, Forestry, Water and Mines (MINITERE) to Ministry of Natural Resources (MERENA) in an attempt to avoid liquidation and payment of its debts. Many companies close down without following proper procedures leaving creditors with little or nothing to assure payment of their claims. For the former RG, Louise Kanyonga, 'it is a huge problem for the registrar's record as we cannot be sure which company is active and which is not'. ${ }^{59}$

The number of active companies is less than registered companies. This issue is very crucial, and there are plans to organize a survey on the causes of the closing down of many businesses and why businesses do not prefer the insolvency proceedings to avoid all adverse consequences created by the clandestine closing out. Practically, there are two causes for the closing down of businesses in Rwanda: firstly, it is due to lack of finance to continue with business. Secondly, there is lack of awareness and understanding of the insolvency procedures, and benefits of insolvency proceedings. The lack of awareness of the RIL, its procedures and benefits of insolvency among the business community also accounts for the underdevelopment of the culture of filing for insolvency. ${ }^{60}$ These problems are compounded by the fact that there are no monitoring mechanisms to monitor registered companies and the fact that the systems are not speaking to each other. In other words, there is no communication between the office of the RG, the companies and Rwanda Revenue Authority making it difficult to determine financially distressed companies and those that have been closed down. Although not a government responsibility, the lack of communication between the systems frustrates the country's purpose of development and survival of businesses.

Nevertheless, there are efforts to promote the RIL among the business community in order to improve the country's ranking on resolving insolvency that currently stands at 137 with a significant rise of 29 positions (rank 166 in 2013). ${ }^{61}$ Several trainings on the RIL, its procedures and benefits of insolvency were effected by the author. Booklets on the RIL were equally prepared to facilitate understanding of the RIL.

56. Supra note 53.

57. T Jean de la Croix, before note 53 at 1.

58. Judgment Rcom 0156/011/TC/Nyge of 10 February 2012.

59. K Agutamba 'Legal minds punch holes in new insolvency law' The Rwanda Focus 7 May 2012 at 1 (hereinafter referred to as $\mathrm{K}$ Agutamba). See 'Rwanda: Country struggles on insolvency law', available at: <http://allafrica.com/stories/201205141215.html> (accessed 28 January 2014). Currently, there are a handful of insolvency cases pending before the commercial courts in Rwanda.

60. This is following a survey conducted by the author (2013, unpublished and on file with author).

61. See Doing Business 2014 Data for Rwanda, available at: <http://www.doingbusiness.org/data/ exploreeconomies/rwanda?topic $>$ (last accessed 22 January 2014). 


\section{Functionaries in an insolvent estate}

The relevance of an efficient insolvency framework is widely acknowledged especially within the current economic context that dictates that the insolvency industry should be properly regulated. Regulation of the insolvency profession is a dominating theme in Rwanda, and the state plays a significant role in the regulatory process. The RG acts as 'insolvency regulator' and possesses the power to supervise insolvency proceedings and to regulate the appointment of persons responsible for the administration of insolvency estates by setting down criteria for the appointment of insolvency administrators and the practice of insolvency in the country. ${ }^{62}$ In Rwanda, insolvency representatives are called insolvency administrators whether in the event of rescue or liquidation of an insolvent estate. Insolvency administrators are responsible for the administration of insolvent estates. ${ }^{63}$ Insolvency administrators are appointed by the competent commercial court from a list approved by the RG. ${ }^{64}$ Appointments are randomly made, but knowledge, experience and personal connections play a significant role in the appointment process. The board of directors is equally empowered to appoint liquidators and administrators. ${ }^{65}$

Article 3 of the Instructions of the RG on insolvency ${ }^{66}$ establishes the system of licensing for insolvency administrators who must be eligible for registration. To qualify for appointment as such, the person must be 21 years of age residing in Rwanda and a holder of a bachelor's degree in law, accounting, management, economics or any other related fields. ${ }^{67}$ No special qualification, knowledge or experience to act as insolvency administrator is required. This has resulted in poor understanding and interpretation of the applicable laws by the insolvency administrators. In the author's view, the poor quality of the insolvency administrators is also behind the lengthy and costly insolvency processes in the country. Some of the insolvency administrators are not competent to undertake the work to which they are appointed and to exercise the powers given to them within 2 years starting from the date of the granting of the insolvency order. This is because they are not appropriately qualified and lack knowledge of insolvency law, and relevant commercial, finance laws, as well as adequate experience in commercial and financial matters including accounting.

Currently, it takes years for insolvency proceedings to be completed from start to finish. As to the effect of long standing proceedings, it creates uncertainty for all parties involved and reduces the assets of the estate and, hence, creditors'

62. RIL, art 5.

63. An administrator is a natural person appointed during insolvency proceedings in order to administer an insolvent estate; Id, art 2 (6).

64. Id, art 6.

65. Companies Law, art 218 provides a director of a company who establishes that the company is unable to pay its debts as they fall due shall forthwith request to convene a meeting of the Board of Directors within five days to consider whether the Board should a liquidator or an administrator.

66. RG Instructions on Insolvency, before note 23.

67. Id. 
chances of recovering outstanding debts. This is bad for the country's performance in the Doing Business ranking in resolving insolvency. ${ }^{68}$

\section{Foreign assets (cross-border insolvency)}

In the era of globalization, it is not uncommon for companies to have assets, debtors and creditors located across jurisdictions, but it is surprising for a company to face multiple bankruptcy proceedings outside its country of incorporation, each subject to different rules and handled by different office holders. The RIL does not provide for cross-border insolvency, and Rwanda is not a party to any convention or international treaties on insolvency. This may result in businesses being reluctant to operate beyond the borders of Rwanda for the fear of the unknown in the event of insolvency. The subject of cross-border insolvencies has been researched by the author under the direction of the former RG. The report proposed the adoption of the Model Law, and the idea was embraced by the former RG. However, the RIL is not silent as to assets of a foreign debtor situated in Rwanda. Article 98 provides

in case of a foreign company which operates in Rwanda or if the debtor is a foreigner, the insolvency proceedings shall be subject to Rwandan law on insolvency, unless the international agreement signed between Rwanda and one or more countries provides otherwise. $^{69}$

Article 98 of the RIL limits the applicability of the RIL to the geographical area governed by the state, in particular, where the debtor has assets (territorial approach). In respect of foreign debtors, proceedings shall be limited to assets located within the republic. When the foreign debtor is put into liquidation, the appointed liquidator shall make an advertisement in a newspaper, invite creditors to proof their claims and apply to court for distribution of the net amount recovered. ${ }^{70}$ Insolvent estate relates only to assets owned by the debtor on the date of commencement of insolvency proceedings and those acquired during the proceedings (insolvent estate). ${ }^{71}$ This of course means that after acquired assets will constitute a new estate, certain assets are excluded from the insolvent estate for the maintenance or upkeep of the debtor and his family (exempted assets). Exempted assets include the following: earnings from the provision of personal services and all necessary objects of the debtor used to earn a living as well as his beddings, clothing and other domestic assets. $^{72}$

\section{E. Voidable dispositions/transactions and related matters}

Another issue worth considering is that related to voidable transactions. Unfortunately, the RIL does not define the terms 'transactions' or 'voidable transactions' but provides for voidable preference whose provisions are dispersed in the law.

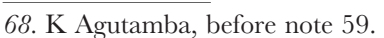

69. RIL, art 98.

70. Companies Law, arts 341 and 342.
71. RIL, art 26.

72. Id, art 43. 
By the provisions of articles 39 and 50 of the RIL, ${ }^{73}$ insolvency administrators are empowered to set aside or invalidate transactions made in a period not more than 6 months prior to commencement of proceedings (voidable preference). The protection that this offers is very limited. While the administrator may set aside transactions entered 6 months prior to commencement of insolvency proceedings, he may not set aside transactions entered beyond the magical 6 months or after commencement of insolvency proceedings by a fraudulent debtor. ${ }^{74}$ In Gemeca $R w a n d a L t d,{ }^{75}$ for example, the insolvency administrator could not set aside transfer made by Gemeca Rwanda Ltd to Gemeca Petrol Ltd because the transactions occurred beyond the magical 6 months.

In seeking to avoid voidable transactions, the insolvency administrator is required to prove that the transaction is illegal and that it satisfies a requirement for avoidance that is intent (intended to avoid, conceal and 'protecting creditors and other related matters'). The words 'protecting creditors and other related matters' is not clear, and it is left for the courts to interpret the precise meaning. As to the effect of avoidance, the transaction will be considered illegal, and the counterparty will be required to disgorge the assets. ${ }^{76}$ Nonetheless, any director or employee of a company who knowingly makes or submits, or authorizes the making or submitting of, a false or misleading statement or report, who fraudulently uses and destroys company's property, and who falsifies a document with intent to deceive a person and for carrying on business fraudulently commits an offence and shall be liable to a fine of between one million to ten million Rwandan francs. ${ }^{77}$

\section{F. Application of proceeds}

The RIL does not in any way facilitate the task of an insolvency administrator in the distribution of proceeds realized from the sale of the debtor's assets. Yes, article 7 of the modified insolvency law provides a ladder for distribution, but it is confusing and contradictory to other relevant laws. Article 7 provides

The administrator shall settle all claims immediately after the confirmation of the administrator's distribution record, in the following order of preference: $1^{\circ}$ the costs of maintaining, conserving and sale of the asset, administrator's fees and expenses incurred, wages and salary of any person engaged in the administration of the estate and expenses incurred by the court or through any other legal acts; $2^{\circ}$ secured creditors on the basis of their ranks with interest calculated in the prescribed manner; $3^{\circ}$ creditors with the right to retain an item in consideration of the improvement they have to make on it; $4^{\circ}$ funeral and testamentary expenses made on the property of the deceased debtor; $5^{\circ}$ salaries or other wages of former employees of the insolvent person for a

73. Id, art 39 provides. If the debtor passes on any item involved in the insolvency proceedings on the commencement of the proceedings, the transfer shall be considered as illegal and such items shall be returned together with their interestswhile art 50 provides. Transactions made in six months prior to the commencement of insolvency proceedings may be invalidated by the administrator if contested against in Court on the evidence that such transactions were aimed at avoiding, concealing and protecting creditors and other related matters. 74. Id.

75. Judgment Rcom 0315/011/Nyge/2012 of 7 October 2012.

76. RIL, art 39.

77. Companies Law, arts 366-371 and 373. 
period of six months; any payment in respect of any period of leave or holiday due to the employee which has accrued as a result of his/her employment contract with the insolvent person in the year preceding insolvency; any payment due in respect of any other form of paid leave for a period not exceeding three months prior to the date of the liquidation of the estate and any severance pay due to the employee in accordance with law, agreement or regulations relating to wages; $6^{\circ}$ social security contributions; $7^{\circ} \mathrm{Gov}$ ernment taxes; $8^{\circ}$ Unsecured claims. After the confirmation of the final plan of distribution, the insolvency administrator shall submit the surplus to the debtor. ${ }^{78}$

Workers are accorded the fifth position after payment of the cost of proceedings, secured creditors and lien holders. This position does not significantly enhance the protection of employees' entitlements because workers of insolvent or asset-poor companies are often left with nothing to assure payment of their claims. This problem is compounded as owners and managers of financially distressed companies operate them to the point of no return. Despite the amendment of the law, it is still difficult to reconcile article 7 (5) and 85 of the labour law. Article 7 (5) contradicts article 85 of the Labour Law that provides

In case of insolvency or legal liquidation of the company, any worker employed in that company has right to payment before any other debt settlement even where such debt is owed to Government. He/she enjoys such right on both movable and immovable properties belonging to the employer.

Put differently, a worker is accorded first priority over a company's movable and immovable assets in the event of insolvency or liquidation over secured creditors. With this, the question is how do we reconcile articles 7 (5) of the modified insolvency law and 85 of the Labour Law?

In the words of article 3 (1) of the RIL, the insolvency law is designed to promote and maintain timely collective mechanisms and procedures for dealing with problems arising from...insolvency. Article 3 (1) allows for collective proceedings wherein creditors are grouped as a mass in the event of insolvency, while article 63 envisages a non-collective proceeding that involves the payment of secured creditors' once sufficient cash is made available during insolvency proceedings. ${ }^{79}$ This is supported by article 30 of the RIL that provides

a secured creditor with an asset involved in the insolvency proceedings may apply for retention of such an asset and shall not be considered among creditors. In case a secured creditor decides to surrender the security, he/she shall be included on the list of creditors and be paid like other creditors.

Article 32 accords secured creditors the right to retention of their securities during insolvency proceedings. Where a secured creditor decides to retain its security, it

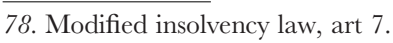

79. RIL, art 63 provides 'Payment of creditors during insolvency proceedings may be initiated only after the general verification meeting. Funds may be distributed among the creditors during insolvency proceedings as soon as sufficient cash is available in the assets involved in insolvency proceedings. Lower-ranking creditors during insolvency proceedings shall not be considered in such distribution. Distribution shall be carried out by the administrator after authorization by the creditors' committee if appointed'. 
will be required to sell the security and distribute the proceeds in accordance with article 22 of the Mortgage Law in the following order of priority:

- payment of any interest, rents, taxes, charges or other amounts due required to be paid on the mortgage ${ }^{80}$;

- payment of expenses incurred and any other amounts due including the remuneration of the receiver ${ }^{81}$;

- payment of the first secured loan or the remaining part thereof, interest or any other circumstances that led to the sale of the mortgage ${ }^{82}$; and

- payment of any additional mortgage in order of their priority. ${ }^{83}$

Free residue is the balance remaining after settling all claims subjected to a security. The balance remaining is paid to the owner of the mortgaged asset (debtor). ${ }^{84} \mathrm{~A}$ secured creditor is left with no remedy in the event where the proceeds of a security are insufficient to meet his or her claims in full. The CASSAVA Co. Ltd v Development Bank of Kigali Ltd $(B R D)^{85}$ is a glaring example.

\section{Some Remarks Regarding the Current Framework on Insolvency}

As indicated earlier, the RIL has been modified, and the modified law brought significant changes to the law and practice of insolvency in Rwanda. That notwithstanding, the RIL is badly drafted, and the sequence of the statutory presentation is poorly carried out. Principles and concepts are not clearly expressed thus making it difficult to comprehend the law. There is also improper choice of words such as low-ranking creditors and claims that have been interpreted as unsecured creditors and claims, ${ }^{86}$ and registration of claims instead of proof of claims. It follows from the foregoing that there is a need for an improved insolvency law regime in Rwanda. It is submitted that an improved insolvency regime will significantly improve the practice of insolvency leading to a speedy resolution of insolvency disputes. As indicated earlier, it would build confidence among credit providers, resulting in increased credit and reduced borrowing costs, facilitate the resuscitation of viable businesses, thereby maximizing the going concern value and preserving jobs, and also benefit entrepreneurs and lower the rate of liquidation of distressed firms. ${ }^{87}$

In order to reform the current framework, it is submitted that a comprehensive overhaul of the regime in general should occur. The need, therefore, to undertake a holistic review of the Rwanda insolvency regime to ensure it remains effective, consistent and fair in a modern commercial context cannot be overemphasized. Although such an approach is rigorous, it is necessary. A holistic approach will give policy makers the opportunity to investigate the law in general and to question certain issues. In view of the weaknesses and inconsistencies discussed earlier, it is vital

80. Mortgage Law, art 22 (1).

81. Id, art 22 (2).

82. Id, art $22(3)$.

83. Id, art 22 (4).

84. Id.
85. CASSAVA Co. Ltd v Development Bank of Kigali Ltd (BRD), Supra note 55.

86. RIL, art 63.

87. IMF, before note 27 . 
to consider international best practices such as the Legislative Guide and the Model Law. This is to maintain public confidence in the insolvency system, to ensure compliance with the underlying principles and to promote regional acceptance of the law.

\section{Law Reform: Use of the Legislative Guide and Model Law}

United Nations Commission on International Trade Law has a long history in insolvency matters ${ }^{88}$ and has adopted a number of international instruments on insolvency and cross-border insolvency, two of which are the Legislative Guide and the Model Law on Cross-border. It should be noted that a Model Law would be used differently to a Legislative Guide. A Model Law is simply a legislative text recommended to states for adoption as part of national law, with or without modification for the settlement of cross-border insolvency disputes. The Model Law does not specify the competent jurisdiction or the applicable law in crossborder insolvency matters. It provides the criteria in determining insolvency proceedings among states, competent jurisdiction to open insolvency proceedings, the applicable law, recognition for such proceedings by other states and cooperation among liquidators and administrators of such proceedings. It follows therefore that states are at liberty to wholly adopt the Model Law or with modification for the settlement of cross-border insolvency disputes.

Recognizing the importance of strong, effective and efficient insolvency regimes in encouraging economic development and investment, the Legislative Guide was adopted to assist the establishment of an efficient and effective legal framework to address the financial difficulty of debtors. ${ }^{89}$ The Legislative Guide is bifurcated into four parts. The first part highlights the policies and purposes and the key objectives of an insolvency law. Part two specifies the core elements of an effective and efficient insolvency law. Part three focuses on the treatment of enterprise groups in insolvency, while part four deals with directors' obligations in the period approaching insolvency. The Legislative Guide is a reference document designed to provide guidance to legislators and other users in the preparation or review of legislation relevant to insolvency. ${ }^{90}$ States are urged to give due consideration when assessing the economic efficiency of their insolvency regimes or when revising or adopting legislation relevant to insolvency. ${ }^{91}$ Interestingly, the Legislative Guide gives states the opportunity to evaluate different approaches in order to decide on the most propitious scenario in the national or local context. ${ }^{92}$

88. P Omar 'Disclaiming onerous property in insolvency: a comparative study' 2010 International Insolvency Review 60-61.

89. Legislative Guide, page 1 para 1.

90. B Wessels (ed) Cross-border Insolvency: International Instruments and Commentary (2007, Kluwer Law International) at 10-11.
91. UN General Assembly, Resolution 59/40. 92. Legislative Guide, page 1 para 1-2. 


\section{G. Proposals for reform}

In view of the inconsistencies and weaknesses discussed earlier, the following recommendations or proposals are made. The recommendations set forth later are designed to improve the existing framework on insolvency, improve the practice of insolvency in Rwanda and hence promote a speedy resolution of insolvency disputes. In addressing the challenges, the author considers that the new insolvency law should include the following:

- Interpretation and general matters, in particular, matters dealing with definitions of key terminologies such as insolvency, avoidance provisions, creditor, commencement of insolvency proceedings, encumbered assets, centre of main interest and cash proceeds. ${ }^{93}$

- The new law should achieve a number of objectives, one of which is to house all insolvency provisions, concepts and principles in one single piece of legislation that is the insolvency law, so as to avoid cross-referencing.

Within the framework, the law must have overall consistency in terms of policy, structure, objectives, concepts, principles, procedures and even language. For the benefit of the debtor and his creditors, the insolvency process should be collective providing for equal treatment of all. In the context of jurisdiction for commencement of insolvency proceedings against corporate debtors, the author recommends the place where the debtor has his registered office, principal place of business or establishment. ${ }^{94}$ The term 'establishment' is defined as 'any place of operations where the debtor carries out a non-transitory economic activity with human means and goods or services'. ${ }^{95}$ Essentially, an establishment is a place of business. ${ }^{96}$ This definition is important to the overall structure of Rwanda where currently there is only one centre of business registration, which is the Rwanda Development Board. ${ }^{97}$ In ensuring this, an amendment of article 4 of the insolvency law is required.

Says the former RG, Louise Kanyonga, 'the statistic on [financially distressed companies] is a sad one - only two out of the ten celebrate their third birthday'. ${ }^{98}$ Claire Akamanzi, former acting chief executive officer of the Rwanda Development Board (RDB), expressed her dissatisfaction on the situation and pointed out that the success of any registered business hinges entirely on its managers. ${ }^{99} \mathrm{In}$ stead of filing for insolvency, many of the failed businesses simply disappeared, leaving employees and creditors empty-handed. In the author's view, it is due to the stigma attached to insolvency and the lack of awareness of insolvency and its procedures among the business community. Insolvencies could be avoided if

93. Id, pages $3-7$ para 12

94. Id, page 5 para 12(q), Companies Law, art 2 (3). Model Law, art 2 (f) defines establishment to mean 'any place of operations where debtor carries out non-transitory economic activity with human means and goods and services'.

95. Legislative Guide, page 5 para 12(q) and Model Law, art 2.

96. Id, page 42 para 15 (b).
97. See 'Rwanda Development Board (RDB)', available at $:<$ http://www.rdb.rw/> (last accessed 22 January 2014).

98. Rwanda Focus 'Rwanda: supplement - new measures to deal with, and avoid, insolvency', available at: < http://focus.rw/wp/2013/05/supplement-newmeasures-to-deal-with-and-avoid-insolvency/ > (last accessed 14 January 2014).

99. Id. 
financially distressed or insolvent businesses are encouraged to seek help at an early stage. The longer a company waits before seeking help, the less likely the business or company will be rescued. To encourage financially distressed or insolvent businesses to voluntarily commence proceedings, a time should be fixed for certainty and transparency for both the debtor and creditors. In this respect, a statutory obligation should exist for debtors to commence proceedings immediately after cessation of payments of debts. ${ }^{100}$ In addition, the Rwanda Insolvency Administrators Body established last year by the author must perform its role as an educator in educating the business community on insolvency, the benefits of insolvency and the availability of rescue proceedings.

As a matter of practice, the choice between reorganization and liquidation proceedings only occurs once the financial situation of the debtor has been assessed and a report submitted herein. A disadvantage of the approach, however, may be the delay that occurs between the decision to commence and the decision as to which proceedings should be followed, and the consequences for the debtor's business and the value of its assets that may flow from that delay. ${ }^{101}$ With a view to protecting creditors and preventing abuse of insolvency proceedings, the law should provide a mechanism enabling administrators to investigate into the debtor's financial situation within 3 months, failing which the administrator should be held liable for any damage, suffered by the debtor or his creditors.

The insolvency of a company or individual has an immediate effect on the rights of the insolvent/debtor, ${ }^{102}$ the creditors and other stakeholders. ${ }^{103}$ There is an inherent need to have those rights protected as quickly as possible. It is therefore important that the bankruptcy process is managed as quickly as is commercially and reasonably possible. In this regard, insolvency administrators should be competent to undertake the work to which they are appointed and to exercise the powers given to them within 1 year starting from the date of the granting of the insolvency order with possibility of extension based on the complexity of the case. This is important because it goes to minimize creditors' risk and cost. In this regard, insolvency administrators should be upskilled through continuous education of the applicable laws as well as by means of specialized training courses that should be provided by Rwanda Insolvency Administrators Body. This will significantly contribute to the ease of resolving insolvency.

It is also vital for the decision makers to devise a mechanism to enable the administration of a debtor with apparently few or no assets under a formal proceeding. In so doing, the law may provide for the appointment of a listed administrator to distribute the available assets of the debtor among his creditors. ${ }^{104}$ The Legislative Guide highlights some of the benefits of devising a mechanism for the

100. Legislative Guide, page 58 paras 59-60. 101. Id, page 19 para 25.

102. The rights of the debtor/insolvent includes the right to be heard, right to access to information relating to the progress of proceedings, where he/she is displaced; RIL, art 38 and right to retain excluded assets for his/her benefit and those of his/her family; RIL, art 43 .

103. Right of stakeholders to payment of their outstanding claims.

104. Legislative Guide, page 62 para 75. 
administration of a debtor with apparently few or no assets under a formal proceeding. In terms of the Legislative Guide, such a mechanism will

Assist in overcoming any perception that such abuse is tolerated and may provide a return for creditors where antecedent transactions can be avoided, as well as a means of investigating the conduct of the management of such debtors. It may also encourage entrepreneurial activity and responsible economic risk-taking through the provision of a discharge and fresh start for entrepreneurs and others engaging in economic activitiesthe punitive and deterrent aspects of insolvency laws will be less appropriate where the debtor is honest. ${ }^{105}$

It is a generally accepted principle of insolvency law that

collective action is more efficient in maximizing the assets available to creditors than a system that leaves creditors free to pursue their individual remedies and that it requires all like creditors to receive the same treatment. ${ }^{106}$

In ensuring that creditors receive a fair allocation of an insolvent debtor's assets consistent with established priorities and preserving the integrity of the insolvency estate, avoidance provisions should have a deterrent effect, discouraging both debtors and creditors from pursuing individual remedies in the period leading up to insolvency and even beyond. ${ }^{107}$ In so doing, articles 39 and 50 of the RIL should be combined because they mean one and the same thing (voidable preference), to enable proper understanding. In addition, articles 39 and 50 should be extended to provide for the different categories: dispositions without value, undue preference and collusive dealings. This will help in recovery of assets or their value for the benefit of creditors. ${ }^{108}$ It will equally help to prevent transactions designed to hide assets for the benefit of the debtor or to benefit the officers, owners or directors of the debtor; to uphold the general enforcement of creditors' rights; to ensure equitable treatment of all creditors by preventing favouritism where the debtor wishes to advantage certain creditors at the expense of the rest; and to prevent a sudden loss of value from the business entity just before the supervision of the insolvency proceedings is imposed. ${ }^{109}$

Having regard to the issue of cross-border insolvency, it is to be noted that as Rwanda seeks to become a business hub, this aspect of cross-border insolvency must be given a legislative clarity, and in so doing, reference must be made to the Model Law. Although 'the enactment of the Model Law without too farreaching modifications would ... facilitate future work towards a more ambitious and comprehensive regime', ${ }^{110}$ the author recommends the adoption of the Model Law with modifications to reflect the national realities in Rwanda. Secondly, the international collective provisions should remain an integral part of the corporate insolvency law, applicable only in the event of cross-border disputes, and thirdly,

105. Id, pages $62-63$ paras $73-74$.

106. Id, page 136 para 151 .

107. Id, page 136 para 151 .

108. Id, page 136 para 152 .

109. Id, page 136 para 151 .
110. Friman 'UNCITRAL Model Law on cross border insolvency: an introduction' 8 and 25. The Model Law does not require reciprocity but does not completely rule out such a requirement. 
there should be two main collective proceedings: primary and secondary proceedings. ${ }^{111}$ Unlike the Model Law, primary proceedings should be commenced where the debtor has its domicile, registered office or establishment, and once initiated, the judgment instituting the proceedings should have the effect of res judicata on the territory of the other member states. On the other hand, secondary collective proceedings should be restricted only to countries where the debtor has assets. ${ }^{112}$ In the event of concurrent proceedings, there should be maximum cooperation between the local courts and the foreign representative. This may be through a designated person or through direct communication of information by any means possible. ${ }^{113}$ The purpose is to 'get rid of time-consuming formalities or diplomatic channels'. ${ }^{114}$ To underline this cooperative spirit, the new law should contain the so-called hotchpot rule. ${ }^{115}$ Article 32 states that

a creditor who has received payment in one proceeding shall not receive payment for the same claim in another proceeding regarding the same debtor if the latter payment would mean that the creditor proportionally receives more than other creditors of the same class of preference.Thus, payment received in one proceeding is taken into account in other proceedings to ensure that all creditors receive at least a dividend.

\section{Conclusion}

Although the insolvency regime lacks well-defined provisions, the legislators should at least be applauded for enacting an insolvency law taking into account the history of the country. As Rwanda struggles to become the business hub in the region and improves its ranking in resolving insolvency, the RIL must be reformed, and key players, that is, the RG, judiciary and insolvency administrators must be properly empowered with knowledge. This is to be achieved through effective training of the RG, insolvency administrators, judicial and court administrative staff on the new law and its procedures. Several trainings were effected by the author, but much needs to be done. The reform of the existing corporate insolvency regime would be a gargantuan task. It is hoped that the business life cycle team made up of the RG, the business community and the insolvency advisor would partner with the legislators to drive the agenda for enthroning a modern but effective and efficient framework in Rwanda. An effective and efficient framework in Rwanda will significantly improve the practice of insolvency leading to a speedy resolution of insolvency disputes.

111. Legislative Guide, page 136 para 151. 112. Model Law, art 2 (c) and (d) and (f). 113. Id, art 27.
114. G Wood Principles of International Insolvency Law (2007, Sweet \& Maxwell) at 966.

115. Model Law, art 32. 